IRA-International Journal of Management \& Social Sciences

ISSN 2455-2267; Vol.05, Issue 01 (2016)

Pg. no. 1-9

Institute of Research Advances

http://research-advances.org/index.php/RAJMSS

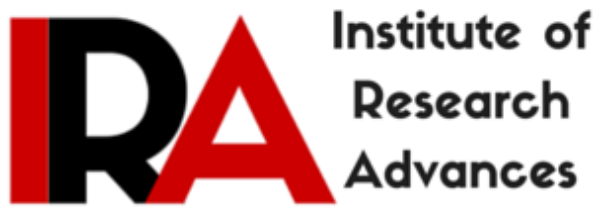

\title{
Financial Statement Analysis of Ashok Leyland Limited, India
}

\author{
${ }^{1}$ Harshadeep Chilukuri \\ Final Year MBA Student \\ RVS Institute of Management Studies and Research \\ Sulur, Tamilnadu-641402, India. \\ ${ }^{2}$ Stephy Thankam Varghese \\ Final Year MBA Student \\ RVS Institute of Management Studies and Research \\ Sulur, Tamilnadu-641402, India.
}

Type of Review: Peer Reviewed.

DOI: http://dx.doi.org/10.21013/jmss.v5.n1.p1

\section{How to cite this paper:}

Chilukuri, H., \& Varghese, S. (2016). Financial Statement Analysis of Ashok Leyland Limited, India. IRA-International Journal of Management \& Social Sciences (ISSN 2455-2267), 5(1), 1-9. doi:http://dx.doi.org/10.21013/jmss.v5.n1.p1

(C) Institute of Research Advances

\section{(c)) EY-NC}

This work is licensed under a Creative Commons Attribution-Non Commercial 4.0 International License subject to proper citation to the publication source of the work.

Disclaimer: The scholarly papers as reviewed and published by the Institute of Research Advances (IRA) are the views and opinions of their respective authors and are not the views or opinions of the IRA. The IRA disclaims of any harm or loss caused due to the published content to any party. 


\section{Introduction:}

The Indian auto industry is one of the largest in the world. The industry accounts for 7.1 per cent of the country's Gross Domestic Product (GDP). As of Financial Year 20142015, around 31 per cent of small cars sold globally were manufactured in India. The Two Wheelers segment with 81 per cent market share is the leader of the Indian Automobile market owing to a growing middle class and a young population.

Moreover, the growing interest of the companies in exploring the rural markets further aided the growth of the sector. India is also a prominent auto exporter and has strong export growth expectations for the near future. In April-January 2016, exports of Commercial Vehicles registered a growth of 18.36 per cent over April-January 2015. In addition, several initiatives by the Government of India and the major automobile players in the Indian market were expected to make India a leader in the Two Wheeler (2W) and Four Wheeler (4W) market in the world by 2020 .

India's second largest commercial vehicle maker Ashok Leyland has shown a declining trend in the total sales during August 2016 by 6 per cent due to lower growth in Medium and Heavy Vehicle segment. The company sold ten thousand eight hundred and ninety-seven $(10,897)$ vehicles in the month gone by, compared with 11,544 units sold in the same month last year. Medium \& Heavy commercial vehicle sales during the month declined 8 percent to 8201 units while light commercial vehicle sales grew by 2 percent to 2696 units on yearly basis. The contribution of Ashok Leyland in the growth of the automobile industry is very high. Hence an attempt is made to analyse the financial statement of Ashok Leyland.

\section{Statement of the Problem}

The role of financial reporting by companies is to provide information about their performance, financial position and changes in the financial position that is useful to a wide range of users in making economic decisions. The role of financial statement analysis is to take financial reports prepared by companies, combined with other information, to evaluate the past, current and prospective performance and financial position of a company for the purpose of making investment, credit and other economic decisions. As several initiatives is taken by the government of India towards automobile industry major automobile players are expected to make India as leader in Commercial vehicles. As Ashok Leyland is one the major player in the Automobile industry in India, conducting financial statement analysis for Ashok Leyland Limited is found importance at this juncture.

\section{Objective of the Study}

The following were the objectives framed by the researcher to analyze the financial statement of Ashok Leyland:

To analyze the Working Capital Position of Ashok Leyland.

$>$ To study the Cash position of Ashok Leyland

$>$ To find out the Profitability Position of Ashok Leyland

$>$ To measure the Returns of Ashok Leyland.

$>$ To study the Efficiency of Ashok Leyland in managing its assets

$>$ To scrutinize the Liquidity position of Ashok Leyland.

\section{Period of the Study}

A period of five years is taken for the analysis purpose from 2011-2012 to 2015-2016 


\section{Tools used for analysis} Limited:

The following tools were used for analysis of financial performance of Ashok Leyland

$>$ Ratio Analysis

$>$ Du-Pont Analysis

\section{Working Capital Analysis of ASHOK LEYLAND}

Working Capital is required to run the day-to-day business activities. It is the amount to be funded for the business operations. Every business firm require working capital, indeed firms differ in their requirements of the working capital. A firm should maintain a sound working capital position. It should have adequate working capital to run its business operations. Both excessive as well as inadequate working capital positions are dangerous from the point of view of a firm. A firm's working capital position is not only important as an index of liquidity but it also used as a measure of the firm's risk.

Analysis of Working Capital as a Percentage of Sales

\begin{tabular}{|c|c|c|c|c|c|}
\hline \multicolumn{6}{|c|}{ (Rs. in lakhs) } \\
\hline Factor & 2012 & 2013 & 2014 & 2015 & 2016 \\
\hline $\begin{array}{l}\text { Non-Cash Current } \\
\text { Assets }\end{array}$ & 427,133 & 428,259 & 540,144 & 596,962 & 714,371 \\
\hline Current Liabilities & 484,314 & 529,610 & 685,402 & 787,270 & 924,272 \\
\hline Working Capital & $(57,181)$ & $(\mathbf{1 0 1 , 0 8 1 )}$ & $(145,258)$ & $(\mathbf{1 9 0 , 3 0 8 )}$ & $(209,901)$ \\
\hline Sales & $1,290,433$ & $1,248,120$ & $1,148,672$ & $1,534,089$ & $2,065,871$ \\
\hline $\begin{array}{l}\text { Working Capital as a } \\
\text { percentage of Sales }\end{array}$ & $(4.43) \%$ & $(8.09) \%$ & $(12.64) \%$ & $(12.40) \%$ & $(\mathbf{1 0 . 1 6 ) \%}$ \\
\hline
\end{tabular}

\section{Inference:}

Working Capital is the amount that is to be funded for day to day operations of the company. The Working Capital Requirement of the firm changes with sales. Here, Working Capital shows negative that clearly indicates the following two reasons.

$>$ Current Liabilities are more than the Current Assets.

$>$ Specifically, negative working capital most often arises when a business generates cash so quickly that it can sell a product to the customer before it has had to pay its bill to the vendor in the later stage. In the meantime, the vendors fund is effectively used in the business.

Working Capital as percentage of sales is negative and it indicates Ashok Leyland company generates cash so quickly. Before paying bill to the vendor, Ashok Leyland is effectively using the vendor's money for rotation in the business for its growth.

\section{Cash Analysis of Ashok Leyland}

Cash is the basic input needed to keep the business running on a continuous basis. It is also the ultimate output expected to be realised by selling the service or product manufactured by the firm. 
The firm should maintain a sufficient amount of cash. Cash shortage will disrupt the firm's manufacturing operations while excessive cash will simply remain idle, without contributing anything towards the firm's profitability. Thus, a major function of the financial manager is to maintain a sound cash position.

\section{Days of Funding in different Components}

(Rs. In lakhs)

\begin{tabular}{|c|c|c|c|c|c|}
\hline Ratio & 2012 & 2013 & 2014 & 2015 & 2016 \\
\hline $\begin{array}{l}\text { Inventory Turnover } \\
\text { Ratio }\end{array}$ & 5.8 & 6.6 & 7.4 & 9.8 & 10.0 \\
\hline $\begin{array}{l}\text { Receivables Turnover } \\
\text { Ratio }\end{array}$ & 10.5 & 8.8 & 8.3 & 11.3 & 13.6 \\
\hline $\begin{array}{l}\text { Payables Turnover } \\
\text { Ratio }\end{array}$ & 5.0 & 5.0 & 4.4 & 5.0 & 7.0 \\
\hline Inventory Days & 63 & 55 & 49 & 37 & 36 \\
\hline Receivables Days & 35 & 42 & 44 & 32 & 27 \\
\hline Payables Days & 73 & 73 & 82 & 73 & 52 \\
\hline $\begin{array}{l}\text { Average Inventory } \\
\text { Period }\end{array}$ & \multicolumn{5}{|c|}{48 days } \\
\hline $\begin{array}{l}\text { Average Collection } \\
\text { Period }\end{array}$ & \multicolumn{5}{|c|}{36 days } \\
\hline $\begin{array}{l}\text { Average Payment } \\
\text { Period }\end{array}$ & \multicolumn{5}{|c|}{71 days } \\
\hline
\end{tabular}

\section{Inference:}

On an average Ashok Leyland requires 48 days to recover the amount stuck as inventory, 36 days to receive the amount out of credit sales from the debtors and 71 days to pay the amount for purchases to the suppliers. The average payment period is more than the average collection period; hence the company is effectively utilizing the suppliers fund in the business for rotation.

\section{Cash Conversion Cycle}

\begin{tabular}{|l|l|l|l|l|l|}
\hline & $\mathbf{2 0 1 2}$ & $\mathbf{2 0 1 3}$ & $\mathbf{2 0 1 4}$ & $\mathbf{2 0 1 5}$ & $\mathbf{2 0 1 6}$ \\
\hline Inventory Days & 63 & 55 & 49 & 37 & 36 \\
\hline Receivables Days & 35 & 42 & 44 & 32 & 27 \\
\hline Payables Days & 73 & 73 & 82 & 73 & 52 \\
\hline $\begin{array}{l}\text { Cash Conversions } \\
\text { Days }\end{array}$ & $\mathbf{2 5}$ & $\mathbf{2 4}$ & $\mathbf{1 1}$ & $\mathbf{( 4 )}$ & $\mathbf{1 1}$ \\
\hline
\end{tabular}




\section{Inference:}

Cash Conversion Cycle tells about the number of days the Company has to fund the business for smooth operations. From the above analysis it is evident that Ashok Leyland requires on an average for 13 days' funds to be supplied for the business on account of inventory, receivables and payables as the average cash conversion cycle for Ashok Leyland is 13 days.

\section{Cash Flow Statement Analysis}

\begin{tabular}{|c|c|c|c|c|c|}
\hline & 2012 & 2013 & 2014 & 2015 & 2016 \\
\hline $\begin{array}{l}\text { Cash from Operating } \\
\text { Activities }\end{array}$ & 114,731 & 72,830 & $(10,400)$ & 49,561 & $(95,180)$ \\
\hline $\begin{array}{l}\text { Cash from Investing } \\
\text { Activities }\end{array}$ & $(105,752)$ & $(116,432)$ & $(37,726)$ & $(12,568)$ & 55,154 \\
\hline $\begin{array}{l}\text { Cash from Financing } \\
\text { Activities }\end{array}$ & 24,112 & 41,698 & 46,129 & 38,065 & $1,24,619$ \\
\hline Net Cash Flow & 33,092 & $(1,904)$ & $(1,997)$ & 75,058 & 84,593 \\
\hline
\end{tabular}

\section{Inference:}

Cash from Operating activities is on decreasing trend up to 2014, the increase is at a higher rate in the year 2015 due to increase in the sales and suddenly decreased in the year 2016. Cash from operating activities is not going in line with profit after taxes due to working capital mismanagement in the company. Cash from investing activities of Ashok Leyland is negative from the year 2012 to 2015 due to huge amount of capital expenditures made by the company for modernization and expansion activities. Cash from financing activities of Ashok Leyland is almost shows increasing trend. Net Cash Inflow, indicates they are not repaying any loans or they are raising money from different sources. The net cash flow available in Ashok Leyland for the usage has drastically reduced in the year 2014 and showing increasing trend from 2015. In the year 2016 the company has raised more fund from outside sources and they have also got some funds by selling assets but the cash inflow from operations is negative due to reduction in sales. This indicates that the company has to take effective measures to increase the sales in the forthcoming years.

\section{Profitability Analysis of Ashok Leyland}

The primary objective of a business undertaking is to earn profits. A business needs profits not only for its existence but also for expansion and diversification. The investors want an adequate return on their investments, workers want higher wages, creditors want higher security for their interest and loan and so on. Profits are, thus a useful measure of overall efficiency of a business.

(Rs.in Lakhs)

\begin{tabular}{|c|c|c|c|c|c|c|}
\hline Ratio & 2012 & 2013 & 2014 & 2015 & 2016 & CAGR \\
\hline EBITDA Margin & $10.05 \%$ & $7.52 \%$ & $4.48 \%$ & $11.12 \%$ & $14.93 \%$ & $10.40 \%$ \\
\hline EBIT Margin & $7.31 \%$ & $4.47 \%$ & $(0.13) \%$ & $7.34 \%$ & $12.39 \%$ & $14.10 \%$ \\
\hline PAT Margin & $4.39 \%$ & $3.47 \%$ & $(2.02) \%$ & (1.39)\% & $5.32 \%$ & $4.92 \%$ \\
\hline
\end{tabular}




\section{Inference:}

Both EBITDA Margin and EBIT Margin decreases in the year 2014 and from 2015 to 2016 it is showing increasing trend. The growth rate (CAGR) of EBITDA Margin is $10.4 \%$ and EBIT Margin is $14.1 \%$. This shows good sign for the company. PAT margin when compared to EBITA margin is very less due to the depreciation expenses as the company has spent lot of the amount on fixed assets in the last two years. The company has also increased its short term and long term borrowings in the last two years which increased the interest expenses. Overall the profitability of the company has improved in 2015-16 and the profitable position of the company is improving which is good for the company.

\section{Analysis of Returns in Ashok Leyland}

The profitability and efficiency of the business is measured to find out the return that the firm has earned by employing capital and assets. This analysis measures the efficiency by comparing the capital employed and it return at various stages. This analysis is considered to be much important as its gives the percentage of returns earned by employing capital and assets.

(Rs.in Lakhs)

\begin{tabular}{|l|c|c|c|c|c|c|}
\hline \multicolumn{1}{|c|}{ Ratio } & $\mathbf{2 0 1 2}$ & $\mathbf{2 0 1 3}$ & $\mathbf{2 0 1 4}$ & $\mathbf{2 0 1 5}$ & $\mathbf{2 0 1 6}$ & CAGR \\
\hline Return on equity & $13.44 \%$ & $9.73 \%$ & $(4.11) \%$ & $2.97 \%$ & $21.45 \%$ & $12.39 \%$ \\
\hline Return on Asset & $7.92 \%$ & $4.26 \%$ & $(0.09) \%$ & $5.77 \%$ & $11.15 \%$ & $8.92 \%$ \\
\hline $\begin{array}{l}\text { Return on Capital } \\
\text { Employed }\end{array}$ & $14.50 \%$ & $7.76 \%$ & $(0.16) \%$ & $10.49 \%$ & $20.33 \%$ & $8.81 \%$ \\
\hline
\end{tabular}

\section{Inference:}

The ROE of the company has declined rapidly in the year 2014, but it has increased in the year 2015. From above we can see ROE increased rapidly in the year 2016. This clearly depicts that the returns available to equity shareholders is improving. Hence the profitability and efficiency of the company is improving.

The ROA of the company is showing a declined rapidly in the year 2014, but it has increased in the year 2015. From above we can see ROA increased in the year 2016. This states that the company has taken effective steps to use its assets efficiently to improve the earnings of the company. Therefore, ROA shows an improving trend.

The ROCE helps the firm in devising the future business policies for the expansion or diversification. ROCE of the company shows a declining trend in the years 2012-2014, but it has increased in the 2015, 2016 depicting that the company has extensively planned for the expansion activities.

Overall the profitability and efficiency of the firm in increasing, its returns are improving.

\section{Leverage Analysis of Ashok Leyland}

The long-term solvency of the firms is found using leverage analysis. Solvency refers to the ability of the firm to meet its long term obligations. The long term creditors of a firm are primarily interested in knowing the firm's ability to pay regularly interest on long term borrowings, repayment of the principal amount at the maturity and the security of their loans. The leverage analysis indicates the firm's ability to meet the fixed interest and costs and repayment schedules associated with its long-term borrowings. 
(Rs.in lakhs)

\begin{tabular}{|c|c|c|c|c|c|c|}
\hline Ratio & 2012 & 2013 & 2014 & 2015 & 2016 & CAGR \\
\hline $\begin{array}{l}\text { Interest Coverage } \\
\text { Ratio }\end{array}$ & 3.7 & 1.5 & $(0.02)$ & 1.3 & 2.6 & $(8.44) \%$ \\
\hline Debt Equity Ratio & 0.57 & 0.79 & 1.69 & 1.56 & 1.74 & $32.18 \%$ \\
\hline Debt Asset Ratio & 0.20 & 0.27 & 0.39 & 0.36 & 0.38 & $17.40 \%$ \\
\hline
\end{tabular}

\section{Inference:}

Interest coverage ratio shows that the company is having enough earnings to pay its interest for debts. The interest coverage position of the company was on a comfortable zone in the years 2012 as the ratio is above 3 . In the years 2013 to 2016 the interest coverage has declined below 3 and the company has to be caution in this issue and try to improve its efficiency in using its assets, reducing expenses and improving profitability to have comfortable earnings to meet its interest expense. In 2016, coverage ratio is almost near to 3 . This indicates company has taken necessary steps to increase the interest coverage ratio.

Debt Equity ratio reflects the relative claim of creditors and shareholders against the assets of the firm. As Long term borrowings is more, the company has more Debt to Equity ratio in 2014-2016. The company has to take necessary actions to maintain company in good position.

Debt Assets ratio is to determine the financial risk of the business. It is stable in the company which clearly indicates that the company has effectively used its borrowings to its assets.

\section{Efficiency Analysis of Ashok Leyland}

Funds are invested in various assets in business to make sales and earn profits. The efficiency with which assets are managed directly affects the volume of sales. The better the management of assets, the larger is the amount of sales and the profits. Turnover ratios measure the efficiency and effectiveness with which the firm manages its assets.

\begin{tabular}{|l|l|l|l|l|l|l|}
\hline \multicolumn{1}{|c|}{ Ratio } & $\mathbf{2 0 1 2}$ & $\mathbf{2 0 1 3}$ & $\mathbf{2 0 1 4}$ & $\mathbf{2 0 1 5}$ & $\mathbf{2 0 1 6}$ & CAGR \\
\hline $\begin{array}{l}\text { Inventory Turnover Ratio } \\
\text { (Times) }\end{array}$ & 5.79 & 6.58 & 7.44 & 9.79 & 10.03 & $14.72 \%$ \\
\hline $\begin{array}{l}\text { Receivables Turnover } \\
\text { Ratio(Times) }\end{array}$ & 10.48 & 8.79 & 8.32 & 11.33 & 13.63 & $6.79 \%$ \\
\hline $\begin{array}{l}\text { Payables Turnover } \\
\text { Ratio(Times) }\end{array}$ & 5.02 & 5.02 & 4.43 & 4.98 & 6.97 & $8.55 \%$ \\
\hline $\begin{array}{l}\text { Fixed Assets Turnover } \\
\text { Ratio }\end{array}$ & 1.70 & 1.42 & 0.99 & 1.28 & 1.50 & $(3.08) \%$ \\
\hline
\end{tabular}




\section{Inference:}

Inventory turnover Ratio is a measure of the number of times inventory is sold or used in a time period such as a year. Here, it's showing increasing trend (2012-2016). It indicates good sign for the company. Here the company Inventory turnover is almost 5-10 times, they keep on replenishing the inventory. Hence the company is efficient in the inventory management.

Receivables turnover ratio is an activity ratio, measuring how efficiently a firm uses its assets. Receivables Turnover Ratio of the company started decreasing trend from 2012-2014 indicating poor management of receivables. From the year 2015 the ratio increased which clearly depicts that the company has taken steps to improve the receivables collection and reduce debtors.

Payables Turnover ratio has decreased in the 2014 which is good signal for the company. Lower the ratio better in managing the payables, higher ratio indicates that the company is delaying the payment to its suppliers which is not good. Suppliers will not be willing to provide goods to the concerns that squeeze them too much by delaying the payment. From the year 2015 the ratio has increased. This indicates not good sign for the company in making payments to its suppliers. To be in good position, company has to take necessary steps in bringing payable turnover ratio down.

Asset Turnover ratio of the company shows a decreasing trend up to 2014 which indicates that the assets were not properly utilized in the company to the fullest capacity to increase the profitability position of the company. From 2015, the company Asset turnover ratio shows increasing trend. This indicates company has taken necessary steps in increasing the Profitability of the company. It's a good sign for the company.

Fixed Assets Turnover ratio of the company shows a decreasing trend up to 2014 which indicates that the fixed assets were not properly utilized in the company to the fullest capacity to increase the profitability position of the company. From 2015, the company Fixed Assets turnover ratio shows increasing trend. This indicates company has taken necessary steps in utilizing their fixed assets and it helps in increasing the Profitability of the company. It's a good sign for the company.

Overall, this indicates Ashok Leyland is efficiently managing its assets.

\section{Liquidity Analysis of Ashok Leyland}

Liquidity refers to the ability of a company to meet its current obligations as when those become due.

\begin{tabular}{|c|c|c|c|c|c|c|}
\hline \multicolumn{7}{|c|}{ (Rs. in lakhs) } \\
\hline Ratio & 2012 & 2013 & 2014 & 2015 & 2016 & CAGR \\
\hline Current Ratio & 0.89 & 0.81 & 0.87 & 0.96 & 0.99 & $2.69 \%$ \\
\hline Quick Ratio & 0.26 & 0.27 & 0.29 & 0.37 & 0.38 & $9.95 \%$ \\
\hline
\end{tabular}

\section{Inference:}

The Current Ratio reveals the relationship between current assets and current liabilities. This ratio also reveals that how efficiently the working capital of the firm is used. If Current Ratio is equal to 2, it indicates that the concern has the ability to meet current obligations. Here the Current Ratio has decreased in 2013 and then its showing increasing trend every year. It is a good Sign for the company. Over all, the Current Ratio is less than 2. It indicates that the concern has difficulty in meeting its current obligations.

The Quick Ratio reveals the relationship between quick assets (current assets - inventories) and current liabilities. This ratio also reveals the ability of the firm to convert its current assets quickly into cash in order to meet its current liabilities. If Quick Ratio is equal to 1, it means that the concern has the ability to meet its very short term obligations. Here the Quick Ratio showing Increasing trend 
every year 2012-2016. It is a good sign for the company. Over all, the Quick Ratio is less than 1. It indicates that the concern has difficulty in meeting its very short term obligations.

Overall the liquidity position of the company is not good.

\section{Suggestions}

1.Reduce Inventory

The average inventory days of Ashok Leyland is forty-eight days which is slightly on a higher side. Hence the company has to take necessary steps to reduce the inventory days by reducing the inventory as lot of working capital is held up in the company has inventory.

\section{Prompt Collections from customers}

The average number of days taken to collect the receivables from the customer is 36 days. The company has to take necessary steps $\mathrm{n}$ sending reminders to its customers, so that they can promptly collect the dues from the customers on time.

\section{Increase Sales}

Ashok Leyland has used lot of outsiders funds and sold some of the assets in the last year to manage the cash flow position. Hence the company has to take necessary steps to increase the advertisement given to their products so that the sales will considerably increase which will in turn increase the earnings of the company.

4.Repay the Debts

The company has to take necessary steps to repay the debt capital as the burden of the company to pay interest has increased. In the last five the company has raised lot of debts from outsiders.

5.Improve the Liquidity Position:

The liquidity position of the company is not good due to less non-cash current assets when compared to current liabilities. Hence the company has to take necessary steps to improve the asset position of the company.

\section{Conclusion}

In the present study analyzing the financial statements of Ashok Leyland it is concluded that the company has to improve the liquidity position. It is also concluded that the company has to take necessary steps to reduce the debt capital proportion.

\section{References:}

1. Annual Reports of Ashok Leyland

2. Websites of Ashok Leyland

3. World Bank Website

4. RBI Website

5. Money Control Website 